\title{
Multidisciplinary Approach on the Corrosion Behavior of Welded Nickel-free and Nickel-containing Stainless Steel Orthodontic Wires
}

\author{
LILIANA POROJAN ${ }^{1 *}$, MIHAELA BIRDEANU², SORIN POROJAN ${ }^{3}$ \\ IVictor Babes University of Medicine and Pharmacy, Faculty of Dentistry, Department of Dental Prostheses Technology, \\ Specialization Dental Technology, 9 Revolutiei 1989 Blv., 300041 Timisoara, Romania \\ ${ }^{2}$ National Institute for Research and Development in Electrochemistry and Condensed Matter, 1 Plautius Andronescu Str., \\ 300224 Timisoara, Romania \\ ${ }^{3}$ Victor Babes University of Medicine and Pharmacy, Faculty of Dentistry, Department of Oral Rehabilitation, Specialization \\ Dental Technology, 9 Revolutiei 1989 Blvd., 300041 Timisoara, Romania
}

\begin{abstract}
The oral environment is responsible to the degradation of metal wires, with consequent release of metal ions in the oral cavity during corrosion, and welded joints are known as areas that are particularly susceptible to corrosion. The aim of the study was to achieve the corrosion behavior of welded Ni-free and Ni-containing stainless steel (SS) orthodontic wires. The morphology and the topography of the laser welded samples were investigated by scanning electron microscopy and atomic force microscopy. The electrochemical measurements calculated the values for corrosion potential, corrosion currentand corrosion rate, for different pH values. Immersion in acidic solution had minimal effect on the corrosion on the joint regions. Ni-free SS wires proved to have a better corrosion resistance, improved by laser welding. Ni-containing SS wires are positive influenced by laser welding, relative to the corrosion behavior.
\end{abstract}

Keywords: corrosion behavior, orthodontic wires, stainless steel, Ni, laser welding

J oining of metal components is frequently necessary to create individual orthodontic appliances and to achieve efficient treatments. These rely on the perfect design and condition of orthodontic wires. Nowadays different wires made from different metals and alloys are available [1].

Nickel is one of the most commonly used metals in orthodontic wires. Nickel is known to cause contact dermatitis, to induce allergic reactions, some complexes of nickel have been considered carcinogenic, allergenic, and mutagenic. The oral environment is responsible to the degradation of metal wires, with consequent release of metal ions in the oral cavity during corrosion. It can lead to roughening of the surface and altering of the mechanical properties of the orthodontic materials [2-4].

Brazing, soldering over a temperature of $450^{\circ} \mathrm{C}$, is the conventional method of joining orthodontic wires in different clinical situations. Beside the problems of galvanic corrosion and possibly biocompatibility, brazed joints show a low mechanical strength with high failure rates [5-9].

Broken appliances complicate the orthodontic treatment, including soft tissue irritation, lost of orthodontic anchorage or aspiration of broken parts. Another method employed for joining metal frameworks is laser welding [10-15]. To weld dental alloys, crystals of yttrium, aluminium and garnet (YAG) doped with neodymium (Nd) are mainly used to emit laser beams (Nd:YAG laser) [1621]. In 2005 an interesting alternative with lower investment costs was introduced in orthodontics. Based on the technique of tungsten inert gas (TIG) welding two different devices for orthodontic purposes were developed. The welding heat is produced with the help of a light bow between tungsten anode and metal. The advantages of laser and TIG welding systems is that there is no solder and thus no galvanic corrosion in the joint; however it requires a small focus to perform the weld and a stereomicroscope is desirable for efficient w orking, as well as an Argon shielding atmosphere to stop the oxidation process around the welding zone [22-24]. However, the welded joints are known as areas that are particularly susceptible to corrosion [25].

During years there were parallel developments in both materials and joining technologies.

The aim of the study was to achieve the corrosion behavior of welded Ni-free and Ni-containing stainless steel orthodontic wires, in terms of morphological and electrochemical investigation.

\section{Experimental part}

Materials and methods

For the experimental analyses metallic Ni-containing wires Chromium (Scheu-Dental, Iserlohn, Germany) with the composition $\mathrm{Cr}$ 16.0-19.0; Ni 6.0-9.5; $\mathrm{Mn} \leq 2.0$; $\mathrm{Si} \leq 2.0$; $\mathrm{Mo} \leq 0.8 ; \mathrm{C} \quad 0.05-0.15 ; \mathrm{P} \leq 0.045 ; \mathrm{S} \leq 0.015$; rest Fe and Nifree wires Menzanium (Scheu-Dental, Iserlohn, Germany) with the composition $\mathrm{Cr}$ 16.0-20.0; Mn 16.0-20.0; Mo 1.82.5; $\mathrm{Si} \leq 1.0$

$\mathrm{N} 0.7-1.0 ; \mathrm{Ni} \leq 0.2 ; \mathrm{V} \leq 0.2 ; \mathrm{C} \leq 0.1 ; \mathrm{P} \leq 0.05 ; \mathrm{S} \leq 0.05$; rest Fe were used.

They were laser welded using Orotig XXS (Orotig, Verona, Italy), an Nd:YAG laser with the wavelength of 1064 $\mathrm{nm}$, power $2.5 \mathrm{~W}$, time, $1 \mathrm{~ms}$, frequency $15 \mathrm{~Hz}$, laser spot $1.1 \mathrm{~mm}$ for Chromium and 1.3 for Menzanium, and a spot superposition of $50 \%$.

The morphology and the topography of the samples were investigated by scanning electron microscopy with energy dispersive X-ray analysis SEM / EDAX Model INSPECT S (FEl, Oregon, USA) and atomic force microscope AFM Model Nanosurf $®$ EasyScan 2 (Nanosurf AG, Liestal, Switzerland).

The electrochemical measurements were obtained using a potentiostat Voltalab Model PGZ 402 with the software VoltaMaster 4 v.7.09. This software calculated the values for corrosion potential (Ecorr), corrosion current (icorr) and corrosion rate. The electrolyte used was artificial saliva (Fusayama) with $\mathrm{pH}=2.5,3.5,4.5,5.5,6.5$. For each sample, the open-circuit potential (OCP) vs. time was 
recorded over 30 min and potentiodynamic polarization curves were obtained.

\section{Results and discussions}

The morphological aspect of the wires was examined by SEM, before welding (fig. 1, 2).

AFM images (fig. 3,4 ) of the surface for each of the studied samples were obtained using a scan size of 1.12im $x 1.12 \mathrm{im}$. The contact mode cantilever was used to measure the samples.

The surface roughness was calculated with eq. 1 for the average roughness and eq. 2 for the mean square root roughness.

$$
\begin{aligned}
& S_{a}=\frac{1}{M N} \sum_{k=0}^{M-1 N-1} \sum_{l=0}\left|z\left(x_{k}, y_{i}\right)\right| \\
& S_{q}=\sqrt{\frac{1}{M N} \sum_{k=0}^{M-1 N-1} \sum_{i=0}\left(z\left(x_{k}, y_{l}\right)\right)^{2}}
\end{aligned}
$$
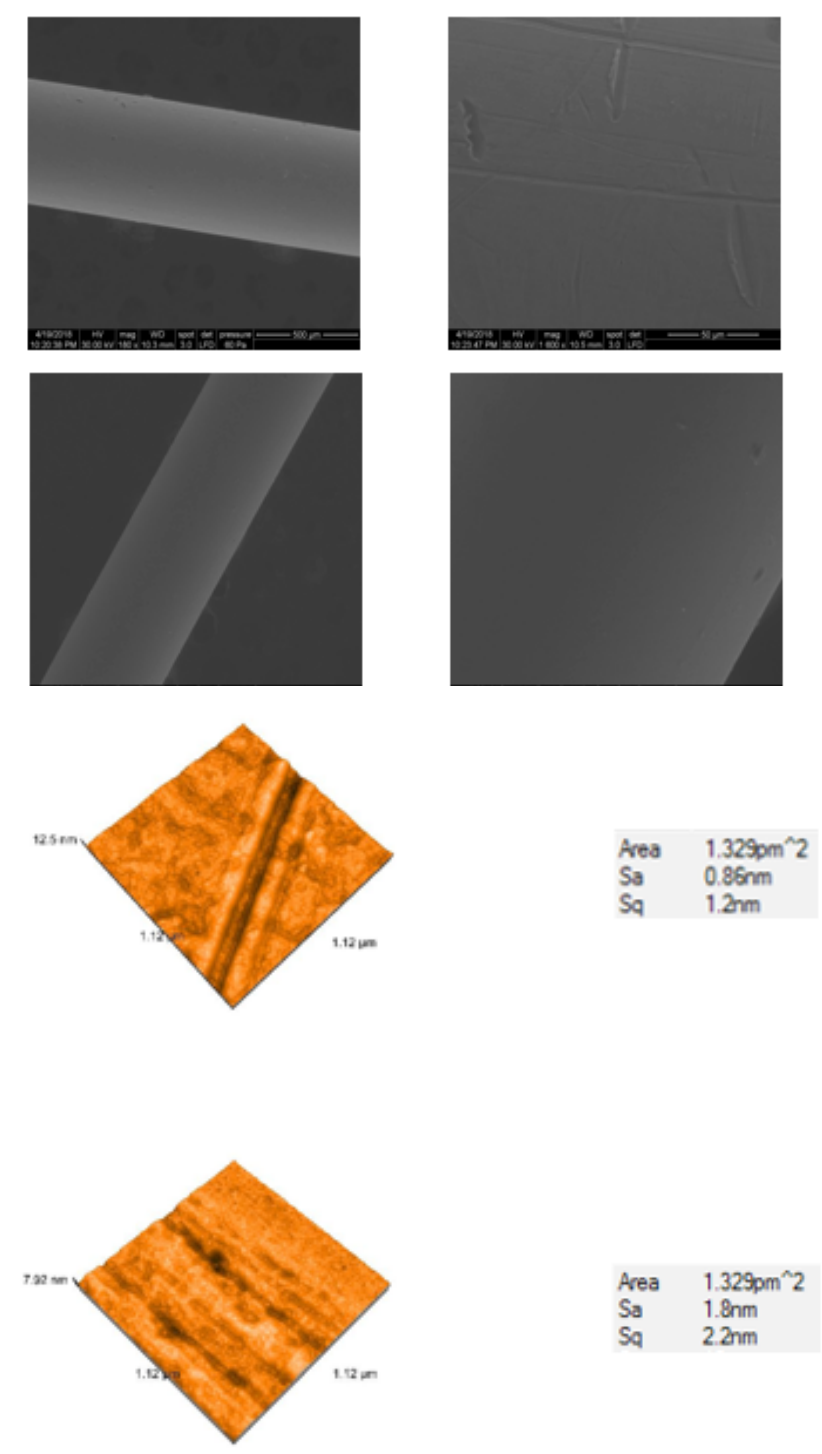

where $\mathrm{N}$ and $\mathrm{M}$ are the crystallites number on $\mathrm{x}$ and $\mathrm{y}$ axis, $z$ being the medium height of the crystallites, $x_{k}$ and $y$ are the maximum and minimum of the crystallites reported to the average value.

After welding, the morphology was examined on both sides (fig. 5, 6).

Electrochemical measurements were made for the corrosion potential (Ecorr), corrosion current (icorr) and corrosion rate (fig. 7).

Considering the potentiodynamic polarization curves plotted in figure 8, the first important remark is that all of the alloys could form a passive film. A higher corrosion current density indicates that the overall corrosion rate will be higher. The corrosion current values were higher for $\mathrm{pH}=2.5$ and non-welded samples, reflecting a higher corrosion rate.

The welded surfaces were more resistant to corrosion, related probably to the surface morphology. The most positive potential indicate the lowestactivation in chemical reaction and the lowest possibility of corrosion.

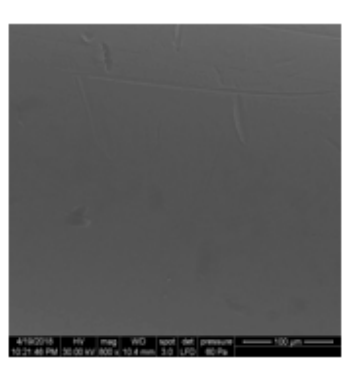

Fig. 1. SEM micrographs showing the structure of Chromium wires, before welding.

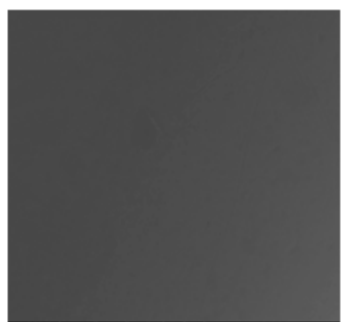

Fig. 2. SEM micrographs showing the structure of Menzanium wires, before welding.

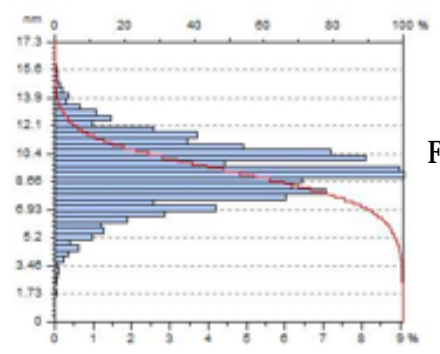

Fig. 3. 3D AFM images and roughness values for Chromium.

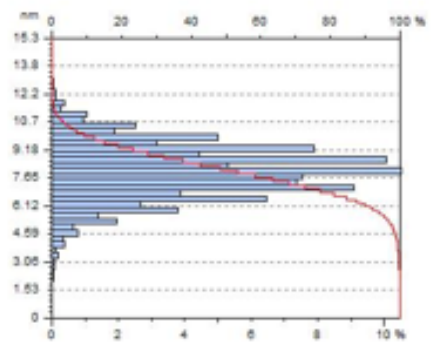

Fig. 4. 3D AFM images and roughness values for Menzanium.

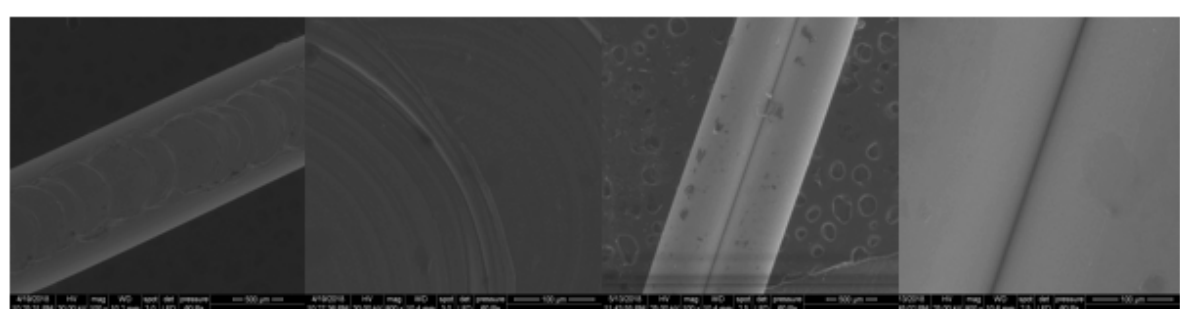

Fig. 5. SEM micrographs for the structure of Chromium wires on both sides, after welding. 


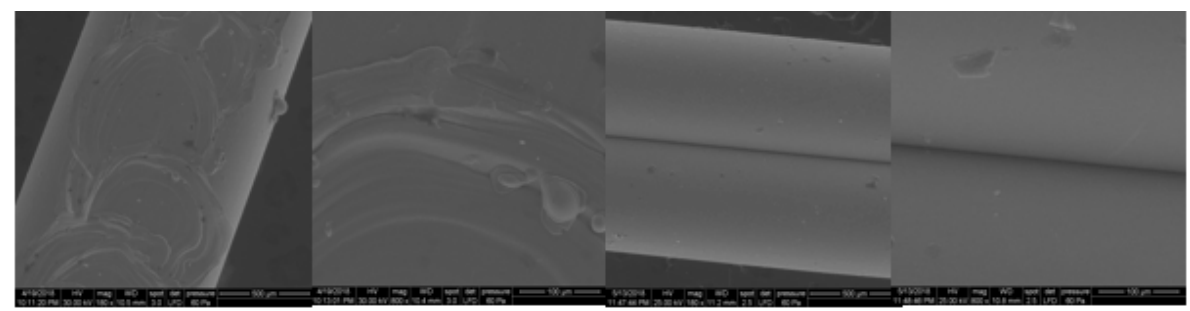

Fig. 6. SEM micrographs for the structure of Menzanium wires on both sides, after welding.
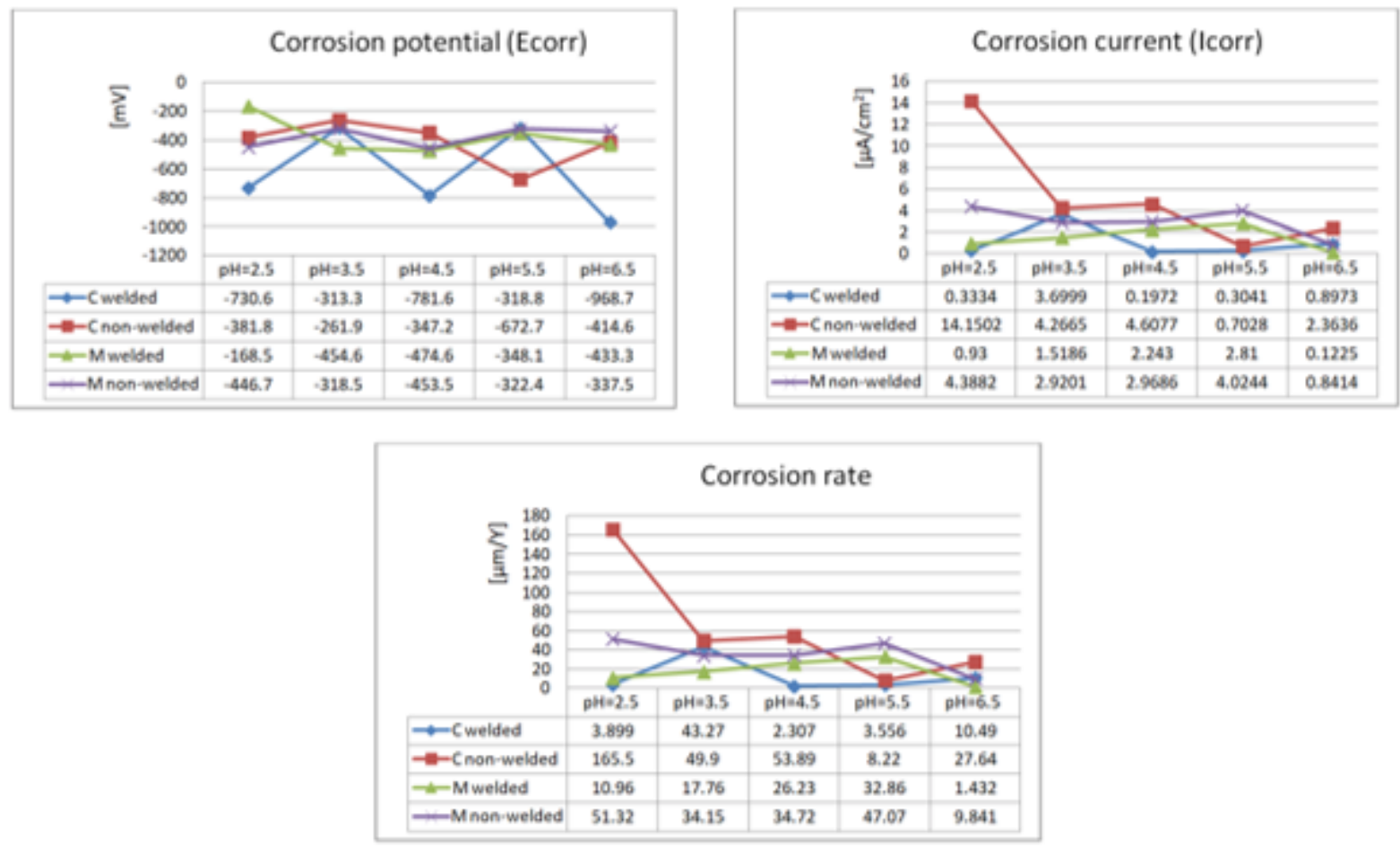

Fig. 7. Electrochemical measurements

a

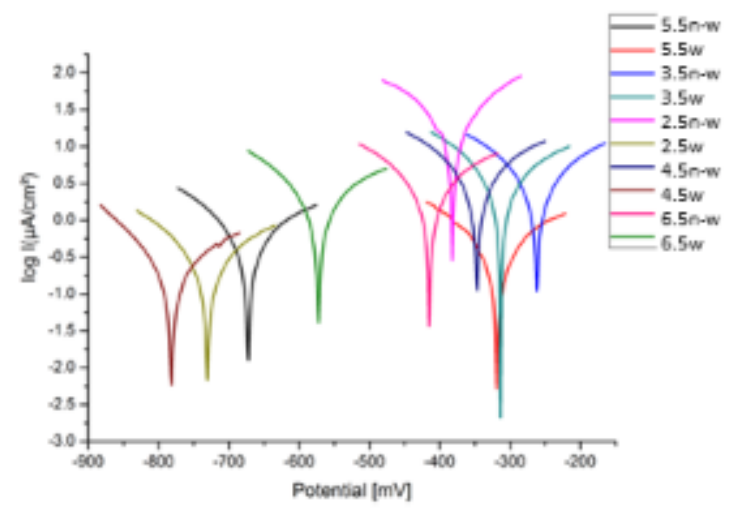

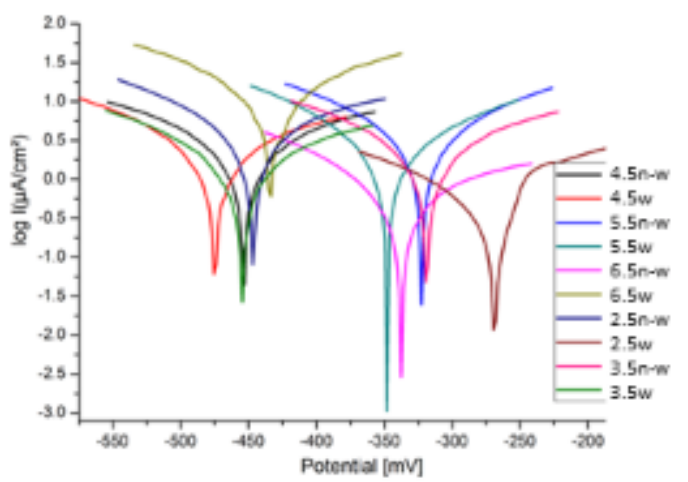

b

Fig. 8. Tafel potentiodynamic polarization curves for: a. Chromium, b. Menzanium

Although no wire is the best for the entire treatment, they must have certain properties such as biocompatibility, formability, weldability, low coefficient of friction, resilience, shape memory, low stiffness, and high elastic limit. Even with the buildup of protective layers, wires exposed to the oral environment can suffer corrosion. Corrosion of orthodontic wires is strongly related with the acidic environment of the buccal cavity. Although the cathodic reaction should be considered for corrosion processes under natural environments, acidic (or even low acidic) environments, are the ones that should be taken into account regarding the corrosion of wires in the oral cavity. SS wires remain popular because of their favourable combination of low cost and excellent formability along with their good mechanical properties. It is a 18/8 $\mathrm{Cr} / \mathrm{Ni}$ austenitic type. Cr forms a thin, adherent passivating oxide layer that provides corrosion resistance by blocking the diffusion of oxygen to the underlying alloy. can be soldered and welded for the fabrication of complex appliances [1].

For Ni-containing wires carbide precipitation occurs when alloys containing both $\mathrm{Cr}$ and $\mathrm{C}$ are heated (chromium carbide $\mathrm{Cr} 3 \mathrm{C} 2)\left(625-815^{\circ} \mathrm{C}\right)$. The quicker the metal is heated and cooled, the less time that $\mathrm{Cr} 3 \mathrm{C} 2$ can form. This combining lowered the $\mathrm{Cr}$ that is available to provide corrosion resistance. Ni possess excellent corrosion resistance to improve weldability, the $C$ content should be as low as possible [26].

For Ni-free wires, Fe-Cr-Mn-Mo-N is a potential replacement in recent years. $\mathrm{Mn}$ is a Ni substituting alloy element, is added to further enhance the $\mathrm{N}$ content. $\mathrm{N}$ is an 
importantalloying elementin terms of corrosion resistance and strength, without affecting their good ductility and toughness properties. High manganese steels contain $12 \%$ or more $\mathrm{Mn}$, and high nitrogen steels include over $0.4 \%$ of $\mathrm{N}$ [27].

The welded joints are known as areas that are particularly susceptible to corrosion. The formation of corrosion products may have the effect of reducing the lifetime of the material. In the case of SS orthodontic alloys, depending on composition, the release of cobalt, chromium, nickel ions can occur that could accumulate in the tissues or migrate to other parts of the human body thereby causing allergies and infections. Nickel ions in particular are considered toxic and carcinogenic and may cause adverse reactions in human body. Corrosion of orthodontic wires is strongly related with the acidic environment [25, 28-30].

Generally, a high OCP indicates a high tendency to resist corrosion. An increase in Ecorr can usually be attributed to an increase in the thickness of the oxide passive film. Ecorr measurements do not provide any information on the kinetics of the corrosion process. This information can be obtained from the corrosion current density (icorr). From the thermodynamic point of view, the acid environment leads to a thinner oxide passive film, reflected through higher corrosion current density values and corrosion rates [31].

The improvement of electrochemical performance could be attributed to the fact that Ni element which possessed excellent corrosion resistance [26].

\section{Conclusions}

Fabricating orthodontic appliances using laser welding has the clinical advantage of biocompatibility, because the welded joint does not require soldered alloy.

Rapid heating due to laser irradiation improves the corrosion resistance of the joint regions.

Immersion in acidic solution had minimal effect on the corrosion on the joint regions.

$\mathrm{Ni}$-free SS wires proved to have a better corrosion resistance, improved by laser welding.

Ni-containing SS wires are positive influenced by laser welding, relative to the corrosion behavior.

Laser welding of SS orthodontic wires should be acceptable for clinical use, successful joinings result due to the good weldability of the SS wires.

\section{References}

1.CASTRO, SM, PONCES, MJ ., LOPES, JD, VASCONCELOS, M, POLLMANN, MCF, Orthodontic wires and its corrosion - The specific case of stainless steel and beta-titanium, J ournal of Dental Sciences, 10(1), 2015, p.1.

2.PETOUMENO, E, KISLYUK, M, HOEDERATH, H, KEILIG, L, BOURAUEL, C, JAGER, A, Corrosion susceptibility and nickel release of nickel titanium wires during clinical application, J Orofac Orthop, 69, 2008, p.411.

3.KAO, CT, DING, SJ, HE, H, CHOU, MY, HUANG, TH, Cytotoxicity of orthodontic wire corroded in fluoride solution in vitro, Angle Orthod, 77, 2007, p. 349.

4.LILIANA, P , ELENA, SC, VIRGIL, CL, LAURENTIU, DM, DANIEL, PS SORIN, Corrosion Behavior of $\mathrm{Ni}-\mathrm{Cr}$ Dental Casting Alloys, International J ournal of Electrochemical Science, 13(1), 2018, p. 410. 5.BOCK, JJ, BAILLY, J, FUHRMANN, RA, Effects of different brazing and welding methods on the fracture load of various orthodontic joining configurations, J Orthod, 36(2), 2009, p. 78. SOLMI, R, MARTINI, D, ZANARINI, M, ISAZA, PENCO, S, RIMONDINI, L, CARINCI, P, BOREA, $G, R U G G E R I, A$, Interactions of fibroblasts with soldered and laserwelded joints, Biomaterials, 25, 2004, p. 735.
6.YAN, XJ, YANG, DZ, Corrosion resistance of a laser spotwelded joint of NiTi wire in simulated human body fluids, J Biomed Mater Res A, 77, 2006, p. 97.

7.YOKOTA, K, MINAMI, T, MICHITSUJI, H, FUJIO, T, YAMADA, S, Occupational dermatitis from soldering flux, Ind Health, 42, 2004, p. 383.

8.ZUPANCIC, R, LEGAT, A, FUNDUK, N, Tensile strength and corrosion resistance of brazed and laser-welded cobalt-chromium alloy joints, J Prosthet Dent, 96, 2006, p. 273.

9.BABA, N, WATANABE, I, LIU, J, ATSUTA, M, Mechanical strength of laser-welded cobalt-chromium alloy, J Biomed Mater Res B Appl Biomater, 69, 2004, p. 121.

10.BABA, N, WATANABE, I, Penetration depth into dental casting alloys by Nd:YAG laser, J Biomed Mater Res B Appl Biomater, 72, 2005; 72, p. 64.

11.BERTRAND, C, LE PETITCORPS, Y, ALBINGRE, L, DUPUIS, V, Optimization of operator and physical parameters for laser welding of dental materials, Br Dent J, 196, 2004, p. 413.

12.KRISHNAN, V, KUMA, KJ, Weld characteristics of orthodontic archwire materials, Angle Orthod, 74, 2004, p. 533.

13.UYSAL, H, KURTOGLU, C, GURBUZ, R, TUTUNCU, N, Structure and mechanical properties of Cresco-Ti laser-welded joints and stress analyses using finite element models of fixed distal extension and fixed partial prosthetic designs, J Prosthet Dent, 93, 2005, p. 235.

14.VERSTRYNGE, A, VAN HUMBEECK, J, WILLEMS, G, In-vitro evaluation of the material characteristics of stainless steel and beta-titanium orthodontic wires, Am J Orthod Dentofacial Orthop, 130, 2006, p. 460. 15.HUANG, HH, LIN, MC, LIN, CC, LIN, SC, HSU, CC, CHEN, FL, LEE, SY, HUNG, CC, Effects of welding pulse energy and fluoride ion on the cracking susceptibility and fatigue behavior of Nd:YAG laserwelded cast titanium joints, Dent Mater J, 25, 2006, p. 632.

16.IWASAKI, K, OHKAWA, S, ROSCA, ID, UO, M, AKASAKA, T, WATARI, $\mathrm{F}$, Distortion of laser welded titanium plates, Dent Mater J, 23, 2004, p. 593.

17.LIU, J, WATANABE, I, YOSHIDA, K, ATSUTA, M, Joint strength of laser-welded titanium, Dent Mater, 18, 2002, p. 143.

18.WATANABE, I, BABA, N, CHANG, J, CHIU, Y, Nd:YAG laser penetration into cast titanium and gold alloy with different surface preparations, J Oral Rehabil, 33, 2006, p. 443.

19.WATANABE, I, TOPHAM, DS, Laser welding of cast titanium and dental alloys using argon shielding, J Prosthodont, 15, 2006, p.102

20.WATANABE, I, TOPHAM, DS, Tensile strength and elongation of laser-welded Ti and Ti-6Al-7Nb, J Biomed Mater Res B Appl Biomater, 71, 2004, p. 46-51.

21.SESTINI, S, NOTARANTONIO, L, CERBONI, B, ALESSANDRINI, C, FIMIANI, M, NANNELLI, P, PELAGALLI, A, GIORGETTI, R, In vitro toxicity evaluation of silver soldering, electrical resistance, and laser welding of orthodontic wires, Eur J Orthod, 28, 2006, p. 567.

22.SOLMI, R, MARTINI, D, ZANARINI, M, ISAZA, PENCO, S, RIMONDINI, L, CARINCI, P, BOREA, G, RUGGERI, A, Interactions of fibroblasts with soldered and laser-welded joints. Biomaterials, 25, 2004, p. 735. 23.YAN, XJ, YANG, DZ, Corrosion resistance of a laser spotwelded joint of NiTi wire in simulated human body fluids, J Biomed Mater Res A, 77, 2006, p. 97.

24.DANTAS COSTA, J, BAIA DE SOUSA, M, MORAIS LIA FOOK, NC, NICACIO ALVES, J], DE ARAUJ O, CJ, SHIVA, P, NASCIMENTO CAMPOS, AR, DE SANTANA, RAC, Obtaining and characterization of Ni-Ti/Ti-Mo joints welded by TIG process, Vacuum, 133, 2016, p. 58.

25.ZHANG, H, ZHANG, CH, WANG, Q, WU, CL, ZHANG, S, CHEN, J, ABDULLAH ADIL O, Effect of Ni content on stainless steel fabricated by laser melting Deposition, Optics and Laser Technology, 101, 2018, p. 363.

26.TALHA, M, BEHERA, CK, SINHA, OP, A review on nickel-free nitrogen containing austenitic stainless steels for biomedical applications, Mater Sci Eng C Mater Biol Appl, 33(7), 2013, p. 3563.

27.SINGH R, DAHOTRE NB, Corrosion degradation and prevention by surface modification of biometallic materials, J Mater Sci Mater Med, 18, 2007, p. 725. 
28.SUMITA, M, HANAWA, T, TEOH, SH, Development of nitrogencontaining nickel-free austenitic stainless steels for metallic biomaterials - review, Mater Sci Eng C, 24, 2004, p. 753.

29.POROJAN, L, POROJ AN, S, Studies on the Chemical Composition of Welded Base Metal Dental Alloys, Rev. Chim. (Bucharest), 66, no. 4, 2015, p. 507.
30.POROJ AN, S, POROJ AN, L, Evaluation of Co-Cr Dental Alloys Welds Corrosion, Rev. Chim. (Bucharest), 66, no. 3, 2015, p. 357.

31.POROJAN, L, BIRDEANU, M, SAVENCU, C, POROJAN, S, Surface Characteristics and Corrosion Properties of Co-Cr Dental Alloys Processed by Laser-based Methods, Rev. Chim. (Bucharest), 68, no.11, 2017, p. 2538.

Manuscript received: 17.11 .2018 